\title{
THE CURSE OF THE GOLD: DISCOURSES SURROUNDING THE PROJECT OF THE LARGEST PIT-MINE IN EUROPE
}

\author{
Istvan Egresi*
}

Department of Geography, Fatih University, Istanbul, Turkey

\begin{abstract}
In 1996, a Canadian company started geological explorations in the Rosia Montana area in the Romanian Carpathians. Two years later it formed a joint-venture with a Romanian state company to exploit what is believed to be Europe's largest gold reserves. However, as of June 2011 extraction has not started yet and it may never start due to the opposition of numerous NGO's that have pointed out the environmental, social and economic unsustainability of this mining project. This situation is highly unusual for a country that is hungry for foreign investment especially since up until very recently the state had supported any project promising to revitalize its mining sector. This paper will investigate the changes in the discourses surrounding this mining project taking into consideration the effects of globalization and the effects of Romania's EU membership after 2007.
\end{abstract}

Key words: Rosia Montana, Discourse, Gold Mine, Romania, European Union

\section{Introduction: Changing Discourses}

Peet and Watts (1996, p. 14) define discourse as "an area of language use expressing a particular standpoint and related to a certain set of institutions." Discourses do not represent the absolute truth, but rather socially constructed ideas about the truth. Also they are not comprehensive, meaning that only some concepts are emphasized (those serving for the argument) while others are ignored (Peet and Watts, 1996; Hoenneland, 2003).

Willems-Braun (1997) also remarked that ideas are never innocent as mental conceptions most likely either reinforce or challenge existing social and economic arrangements. Therefore, the meaning of a statement cannot be analyzed and judged outside the discourse. It should be interpreted according to the society or the social group that constructed it. The objective of discourse analysis is ontological rather than epistemological as it is not concerned with depicting the world as it is. The aim of discourse analysis is, therefore, to understand how the world is created, maintained and reproduced by certain groups (Hoenneland, 2003).

One of the most prominent discourses is the environmentalist discourse that seems to become more and more popular. This is often time

\footnotetext{
${ }^{*}$ Correspondence address:
}

Email: iegresi@fatih.edu.tr challenging the development discourse. Environmentalists are not rejecting development, but are examining it from a sustainability standpoint (Peet and Watts, 1996). The development discourses on the other hand are based on the laws of accumulation (Schmink and Wood, 1987). There are many cases where "unmitigated ecological disasters are often hailed as resounding economic and political successes" (Schmink and Wood, 1987, p. 38).

The proliferation of environmental discourses and their increase in power and efficiency could also be explained by the globalization of environmental movements through "transnational alliances and networks, multilateral governance through, for example the Global Environmental Facility of the World Bank, and sensitivity to a panoply of local conflicts and resistances" (Peet and Watts, 1996, p. 2).

Probably nowhere is the antagonism between development discourse and environmentalist discourse more evident than in the mining industry because "mining capitals are especially susceptible to ecological threats to their legitimacy due to the direct extensive and highly visible appropriation of nature" (Bridge, 1998, p. 220). The large-scale mining investments that characterize the industry today have the potential of a significant social and economic impact at local and even regional level. This is exacerbated by the fact that generally mining happens in regions with little other economic activities (Bridge, 2003). 
In the past, mining was perceived to bring jobs and development to a region; it was seen as a way to modernity and consequently supported by discourses that emphasized the productive power of technology over nature (Krueger, 2002). Back then the discussion was about environmental transformation, not environmental destruction or degradation (Bridge and McManus, 2000). Consequently, the local communities and the states supported the mining operations.

However, up until quite recently the scale of the mining operations remained small and the environmental impact was generally localized. With the 1980 os the technological strategies changed significantly. Open-pit mining and the use of cyanide heap leaching became widespread. The new discourse emphasizes the ability to make the mining of leaner ores profitable using the latest technologies and know-how. Bridge and McManus (200o, p.35) refer to this as the central theme of the mining discourse lauding "the activity of extracting minute quantities of gold from large amounts of waste ore to generate profit in terms of a socially responsible program undertaken on behalf of the American [or other nationality] people by skilled professionals to efficiently manage scarce resources." The new technology and know-how employed could determine not only the revitalization of national mining industries but also of mining communities.

The new mining techniques not only made the industry more profitable but also increased the scale of the operation as well as the scale of the environmental destruction (Bridge and McManus, 200o). This has contributed to the growing power of the environmentalist movement.

With the environmental groups becoming more popular and more globalized, the relationship that developed between mining companies, local communities and the state became less relevant. The discourse that emphasized tradition, jobs and keeping communities together became less effective when addressing a more heterogeneous public, not impacted by economic and social benefits but suffering from the pollution generated by the mining activities. The industry was forced to reconsider its view of environmental impacts as "latent side-effects to be discussed or justified as an inevitable byproduct of techno-economic progress" (Beck, 1992, p.19 cited by Bridge, 2000 and 1998 and Bridge and McManus, 2000).

Many other groups are implicated now in the dispute on the impacts of mining projects. Among the most active are diverse social movements, development agencies and even shareholders of multinational mining companies concerned about "the effects on share value and future dividends of environmental liabilities and environmentally related delays in project development" (Bridge, 1998, p. 225).

Initially, the mining industry ignored the growing environmentalist opposition. However, it soon realized that the environmentalists could significantly damage the economic feasibility of gold mining projects (Bridge and Mc Manus, 200o). The mining industry had to reinvent itself as a clean, environment friendly industry, embracing the rhetoric of sustainable development (Bridge, 2000). By appropriating a sustainable development discourse, the mining industry intended to disenfranchise the environmentalist discourse (Bridge, 1998). As noted by Bridge and McManus (2000), the mining industry observed on many occasions that the environmentalist groups were not seeking to improve the design of the proposed mines but to proscribe them altogether. The message sent by the new mining industry discourse is that it is possible to have mining development with all economic and social benefits that they bring to the local communities without compromising the environment.

Mining companies have also realized that it is important to maintain a good relationship with the local community. Many such companies have included terms such as "community development" as part of the broader sustainable development and corporate social responsibility frameworks in their communications (Kemp, 2010; Hutchins et al, 2005, Kepore and Imbun, 2010). The idea of community development refers to the company's commitment to local poverty reduction and the realization of human development goals (Kemp, 2010; Hamann and Kapelus, 2004). This implies that the company would commit to social justice and equity in order to make sure that the benefits from the mining project will trickle down to everyone in the community (Hamann and Kapelus, 2004).

Mining companies are taking their discourse orientation towards community development very seriously. They employ professional community development practitioners to interact with the local community and facilitate community development so that local people view their mining operation in a positive light (Kemp, 2010). However, the question remains whether those community development practitioners could privilege the interests of the poor local people over those of the company. Several scholars argued that, in spite of the discourse, when the two interests collide, the business interest will always prevail (Manteaw, 2007, cited in Kemp, 2010). Also many studies have pointed out the gap between the stated intentions of companies and what they actually realize (Frynas, 2005). Moreover, there is a risk that undertaking a corporate social responsibility approach could create dependency of local 
community on the mining company with serious consequences after the closure of the mine (Jenkins and Obara, 2008).

The corporate social responsibility discourse as well as the environmentalist discourse are using science to present their perspective yet their solution to the problem is very different and seem irreconcilable (Hutchins et al, 2005).

I analyze in this paper to what degree the discourses of the mining industry and that of environmentalist groups are following the same model in a developing country. I also want to know what role have the local factors played in shaping the rhetoric of the two stakeholders. My study examines the situation created by a possible opening at Rosia Montana, in the Romanian Carpathians of the largest open-pit gold mine by a Canadian company. And, since Romania joined the European Union in 2007, my study seeks to understand how has this political change influenced the discursive frameworks of the two groups.

\section{The village of Rosia Montana}

Rosia Montana is situated in the south-central part of the Apuseni Mountains, or the Western Branch of the Romanian Carpathians, in a region known as the "Golden Quadrilateral." This area of 500 square kilometers is considered to be one of the richest in gold and silver in Europe (RMGC, 2003).

The area around Rosia Montana has been mined for gold, silver or copper for the last 2000 years or more. Parts of the Roman galleries are still visible today. The Romans extracted gold from Rosia Montana for more than a hundred years. During the great migration period, between the third and the twelfth centuries, the mines were abandoned. They were reopened during the Middle Ages to supply the King of Hungary but it was not until the seventeenth century, during the Habsburgs, when mining extended again to the scale of Roman operations. It intensified during the communist period when new mines were opened and several processing plants started to operate. In the last two decades, however many mines became unprofitable and had to be closed. The processing plants also had to reduce their activity and therefore many people lost their jobs (Buza et al., 2001). The revitalization of the mining industry became the dream of the local people.

\section{The Company}

The Canadian company Gabriel Resources, founded by Frank Timis, a Romanian émigré, started geological explorations in the Rosia Montana area in
1995. Two years later they formed a joint venture with Minvest, a state-owned mining company to exploit what is believed to be Europe's largest gold reserves. The Canadian company owns 80 percent of the newly formed EuroGold Company while the Romanian state and a few minority shareholders retained the rest of 20 percent. In 1999 the company changed its name again to Rosia Montana Gold Corporation (RMGC) (Simion and Brand-Jacobsen, 2002).

The details of the contract between the Romanian government and the Canadian company have not been released spawning speculations that the company could not have closed the deal without having personal ties with important politicians but these allegations could not be proved by subsequent investigations (Hewisz et al, 2009).

The operation at Rosia Montana started as a reclamation project to salvage gold from the vast mining waste left behind by the state-run company; however, after more gold was discovered through exploratory drilling in the area the aim of the project changed (Hewisz et al, 2009). Gold and silver are now planned to be extracted from a series of open pits, near the existing gold mine at Rosia Montana. The development of the Rosia Montana project will cost, according to the company's estimates US\$1 billion. The company hopes to extract 300 tons of gold and 1200 tons of silver in a 16.4 year life span of the mines. The company is working with a budget of over US $\$ 400$ million, but it is expected that, once the operations are started, payback will be achieved in 2.5 years and expected profit, after tax is US\$1.1 billion (GRD Minproc Limited, 2001 and Mining Watch Canada, 2002).

In the early phase, the company did nothing to involve the local community into their project or to create a positive image for the company. They had believed that their good relationships with the Romanian government and with local politicians would ensure approval of the project in an area with chronic poverty and high unemployment rates (Hewisz et al, 2009). They were initially taken by surprise by the organized opposition of the civil society.

\section{The Mining Company's Discourse on Environment}

One element in the company's discourse to show its concern for the environment is the use of the latest technology, which is supposed to be very precise and safe. The tailings pond will be safe-company officials contend-and will ensure no programmed discharge of effluent for "the safe and 
environmentally stable storage of process tailings." Moreover, the tailings management facility will include a "state of the art" cyanide destruct circuit which will actually reduce the levels of cyanide placed in the pond to less than one part per million, which, corporate sources argue, are well below World Bank guidelines and policies, European Union directives and Romanian laws for mining projects which make this project one of the most environmentally friendly mines in Europe. ${ }^{2}$

According to the company, the project is designed to treat most of the run-off from the affected areas and to discharge only in time of flood or heavy snow. Therefore, the new water management, which is a serious concern of the company, not only will assure that the level of pollution will not increase with the opening of the new project but will actually result in an improvement to the current condition of waterways in the vicinity of the project. ${ }^{3}$

When the former Romanian Prime Minister, Adrian Nastase expressed publicly his concerns vis-àvis this project, which were widely reproduced by several Romanian newspapers, Mr. Hushovd, then chairman and CEO commented as follows:

"Gabriel believes the development of the Project is good for Romania and its economy and Gabriel's development plans for the project are environmentally sound. Gabriel is currently preparing its environmental impact assessment for the project, which is being prepared in accordance with all Romanian requirements as well as al European and international standards.

Gabriel welcomes the opportunity to continue to work with the Romanian Ministry of Environment, together with all other Romanian government offices, to understand the environmental impact assessment of the Project, the many environmental projects incorporated in the development plans for the Project, as well as the remediation of historical environmental pollution in the Rosia Montana area." ${ }^{\prime 4}$

Two important ideas for Gabriel's discourse are very visible in the above paragraph. One is that the company does not present itself as a polluter, but rather as a "cleaner" of the pollution produced by others. This is supporting Bridge and McManus's (2000) observation that the mining industry often times claims that modern mining operations will actually improve the state of the environment.

\footnotetext{
${ }^{1}$ The February 25, 2003- Project update, Rosia Montana, www.gabrielresources.com

${ }^{2}$ October 11, 2002- Project update, Rosia Montana, www.gabrielresources.com

${ }^{3}$ Second Quarter Project Update- 2003, www.gabrielresources.com

4 "Gabriel Resources Ltd. Reports that its is not proceeding with the previously announced "bought deal" equity offering," www.gabrielresources.com
}

The second one, which reinforces the first idea, is that the project will be developed in accordance with all Romanian and European laws concerning the environment. Moreover, the company expressed its willingness to continue working with the Romanian Government or other authorities to ensure that the project is environmentally sound.

Company officials argue also that the entire project was scientifically designed by the company engineers, and certified by Romanian specialists and experts representing third parties. For example, the tailings management facility "has been certified by independent Romanian dam experts and specialists and has also been subjected to a third review by an independent international consulting firm specializing in dam design and construction." ${ }^{5}$ This is supposed to give Gabriel's discourse an aura of scientific knowledge, precision and impartiality. It conveys the message that it is not the "profit-hungry" company who designed the project facilities but rather independent experts, who are concerned for their reputation and cannot afford to make mistakes. It is also difficult to accuse foreign companies for intentions of "mercilessly exploiting the Romanian environment" when your countrymen also put their signatures on the document.

David Chambers (2003) from the Center for Science in Public Participation produced a report with technical comments on the Rosia Montana feasibility study and project description where he criticized the optimism displayed by the Company when talking about environmental security issues. He contended that the dam planned by Gabriel is not the safest type in terms of providing stability during earthquake events. He also showed that if the dam was to fail during an earthquake, tailings could be released into the water course below the dam and, since the town of Abrud (13,0oo inhabitants) is situated only two kilometers downstream, a major catastrophe would be unavoidable.

Other studies pointed to the fact that the pond will not be covered so that even if it will not leak-as claimed by the Company-cyanide, which evaporates at 27 degrees Celsius, could enter into the air and from there into the earth and ground water (Simion and Brand-Jacobsen, 2002). Also the project will utilize 42 tons of cyanide per day or more than 15,000 tons a year. This poses numerous risks in transporting, storing and utilizing cyanide. Accidents in transporting cyanide are quite frequent, according to Chambers (2003) and the poorly maintained mountain roads that connect Rosia Montana to the rest of Transylvania present particularly high risks.

\footnotetext{
${ }^{5}$ The February 25, 2003- Project update, Rosia Montana, www.gabrielresources.com
} 
Chambers (2003) observed also that the Company allocated less than \$20 million for closure costs and this do not include any costs for water treatment. He argued that in the United States the closure for mines of similar size have been in the $\$ 30-\$ 60$ million range with an additional \$30-6o million for water treatment costs. This prompted the speculation that after the estimated lifespan of 16-17 years the mines will be left to the Romanian state to deal with the pollution.

There are also studies that challenge the company's claim that the project is in accordance with all Romanian and European Environmental Laws. Fisher and Lengauer (2002) ${ }^{6}$ from the University of Vienna's Institute of Europe argued that, although the project might be conform to the Romanian legislation ${ }^{7}$ it is certainly not in accordance with the laws of the European Union.

\section{Ecologists' Discourse on the Environment}

NGOs and other organizations, like Greenpeace emphasize in their discourse the huge size of the project, the very toxic materials used in processing the ore and the degradation of large areas. All these organizations refer to the project as Europe's largest opencast mine that will level five mountains in the area. Francoise Heidelbroeck ${ }^{8}$, an economist and long-term member of Alburnus Maior argued that:

"Such project cannot and does not exist in Europe. Experts from institutions such as the World Bank, Romanian Academy, European Law Institute as well as many other relevant specialists have confirmed that this is a project with all the ingredients of an economic failure and ecological disaster."

Many numbers are used to show the gigantesque dimensions of this project. For example 400 ha (10oo acres) of land in the Corna Valley will be flooded by a "lake of cyanide" formed behind a 180-meter dam and storing more than 195 million tons of cyanide-laced waste while other 1200 ha (300o acres) will be occupied by waste tip (Simion and Brand-Jacobsen, 2002; Mineral Policy Center et al., 2002). The Baia Mare accident is used to exemplify the vulnerability of these types of projects.

On January 2000 a tailings impoundment near this town in northern Romania broke and nearly $100,000 \mathrm{cu}$. m. of water polluted with high cyanide concentrations spilled into the Sasar River and from there into Lapus, Somes, Tisza and finally it reached the Danube. According to BBC (Northover, 2000), concentrations on river Tisza, some 200 kilometers

\footnotetext{
${ }^{6}$ Translation from the German Original by Veronika Neuhold.

${ }^{7}$ The authors do not have expertise in Romanian legislation.

${ }^{8}$ In Save the Apuseni Mountains (www.rosiamontana.org).
}

from the place of disaster were still 120 times the safe level, despite heavy rain. The same source noted that Esmeralda Exploration Ltd, the Australian company that at the time of the accident owned half of the mine denied any structural failure of the dam and argued that the accident was not an environmental disaster.

However, Hungarian authorities claimed that the spill killed 1241 tons of fish in this country alone (Gergely, 200o) and affected supplies of drinking water for two million people and sued Esmeralda and the Romanian authorities for more than \$10o million (The Sydney Morning Herald, 200o). Yet, only six weeks later another accident at a tailing pond in the same county spilled 20,000 tons of heavy metals into the river systems (Clover, 200o).

The tailings pond at Rosia Montana will hold seven times more cyanide than the Baia Mare one and therefore "the worst environmental disaster since Chernobyl [is] waiting to happen" (Simion and Brand-Jacobsen, 2002). Stephanie Roth (2002), another member of Alburnus Maior showed that countries like Germany, Hungary, Czech Republic, Greece or Turkey have reacted quickly to the Baia Mare accident and have either banned or are in the process of banning the use of cyanide while Romania, the country that had most to suffer from the ecological disaster still accepts it. Also, the environmentalists have argued that the risk for an environmental disaster was the main reason for the withdrawal of the World Bank from the project $^{9}$ (Vidal, 2002).

Although presented in a bombastic style, the potential for pollution and even environmental disaster in the region, once the mine will start to operate is probably real judging upon past experiences presented here and from the comments made by independent scientists on the safety of the future tailings pond or waste tip.

However, the reader should know that this new mine is not supposed to open and operate in the middle of a pristine land as pictured on the environmental NGOs website (see, for example www.rosiamontana.org). The image of an idyllic landscape, conveyed through the numerous pictures found on these NGOs' websites is far from reality (check www.gabrielresources.com for images showing the open-pit mine at Rosia Poieni, only $4 \mathrm{~km}$ from Rosia Montana and images showing acidic water flowing from historical working) as mines have existed here for the last 2000 years, as discussed earlier.

\footnotetext{
${ }^{9}$ Gabriel Resources was turned down a US\$10o million from the International Financial Corporation in 2002 on the grounds that the Project could cause severe social and environmental problems in the region.
} 
The places where these mines and the processing plants are located are among the most polluted in Romania. For example, the plant in Zlatna, only a few kilometers from Rosia Montana releases annually 70$100 \mathrm{t}$ of heavy metal particles (involving mainly cadmium, chromium, copper, iron, lead and zinc) which creates serious respiratory diseases and a very high infant mortality rate (Buza et al., 2001). The severity of the problem is aggravated by the specific topoclimate of the Zlatna Basin with frequent air inversions especially during nights and cold periods that keep the polluted air close to the surface level. Heavy metal dust and acid rains excessively degraded soils over some 30,000 hectares while some 43,000 hectares of woodlands were also damaged by industrial pollution (Stirban et al., 1980, cited in Buza et al., 2001). ${ }^{10}$

Water pollution in the region is no less severe. The main rivers traversing the region, Aries and Ampoiu and their tributaries are heavily polluted with water coming from mining galleries and preparation plants. As a result most of the fish died and drinking water in Turda is affected. Even more problematic is the hazard of cyanide from the waste tip at Baia de Aries (Buza et al., 2001).

The mountains around Rosia Montana are crisscrossed by tens of kilometers of galleries transforming the mountains into a Swiss cheese-like landscape. The waste resulted after the processing of gold and silver is deposited on many hectares of land. And just four kilometers from Rosia Montana, at Rosia Poieni, an open-pit mine from which copper was extracted during the 1980 os reduced a mountain with 400 meters and left behind a lunar landscape (Buza et al., 2001).

The reason why all these "details" were not included into the environmentalist discourse is obvious. However, I argue that the fact that the area is already heavily polluted is not necessarily detrimental to the discourse. Of course, the effect on the public is greater if the historic pollution is hidden, but the fact that Rosians were poisoned for so many years does not mean that they are immune now. By the contrary, it could suggest that the government and the local authorities should think of developing more environmentally sound activities to replace the very polluting and redundant industries of mining and ore processing.

Tourism is a type of activity that, most scholars agree, would be beneficial for the region (Buza et al.,

\footnotetext{
${ }^{10}$ A few more numbers would not hurt in understanding the proportion of the phenomenon. Romanian EPA data show that metal dust in soil exceeds the permitted by an enormous margin: $1070 \%$ for copper (Buza et al., 2001). The density of woodland is only $35-40 \%$ of what it would be under normal conditions, and the vegetative period is shortened by 2-3 weeks (Rusu et al., 2001, cited by Buza et al., 2001)
}

2001; Abrudan and Turnock, 1999; Ungureanu and Ragalie, 2009). The Apuseni Mountains, except for the portions spoiled by mining are very picturesque and the cultural heritage of the region is very valuable. This could attract many tourists, except that the infrastructure is very poor and most of the hotels are dilapidated. Many attractions are very far from railroads or highways and can be reached only on foot by very determined tourists. Rural tourism has an important potential and already tens of operations are established and running (Surd and Turnock, 200o). The area around Rosia Montana would be a little more difficult to integrate into the tourism circuit because of the less appealing landscape. Nevertheless, the Roman galleries, the museum housing many historic tools used for mining or extracting the mineral, as well as the old houses in the center of the town could attract many tourists interested in industrial archaeology (Abrudan and Turnock, 1999)

\section{Discourse on Economic Benefits}

The economic benefits that this project would bring Rosia Montana and Romania are widely discussed in all company documents (RMGC, 2003; Gabriel Resources Ltd., 2003). The directors of Gabriel Resources argue that Romania will benefit a great deal from this project from its 20 percent participation and from the 2 percent royalties on the mine production. Therefore, any profit made by the company will benefit also the country. The company is citing the British-based Oxford Policy Management which claims that the project is estimated to bring Romania US\$19 billion as a direct and indirect investment ${ }^{11}$.

However, independent experts warned about the market fluctuations in the gold price, which could make the mine to close temporarily or prematurely (Chambers, 2003). While the company might not be very much affected, as it expects to payback in $\mathbf{2 . 5}$ years after which they work for profit, the consequences for the region could be dramatic.

Another pessimistic scenario was announced by a group of 83 professors of economics at the University of Bucharest who argued that the project is nothing else but pure speculative stock exchange operation. According to them, all Gabriel Resources wants is to increase the stock value of the company and once the share price rises it would sell its shares and declare bankruptcy without ever actually mining (Mineral Policy Center et al., 2002).

\footnotetext{
${ }^{11}$ Gabriel Resources, Press Release, 3 November 2010, www.gabrielresources.com
} 
Gabriel Resources also claims that the best technologies available to the mining industry (including technologies for cyanide destruction) will be introduced to Romania with this project and this will help to revitalize the Romanian mining industry. Also the project will create many jobs that will require training in state-of-the-art mining methods. These highly skilled workers could then be hired by Romanian mining companies or any other company in the world because their skills and qualifications could compete internationally.

Particularly important for the Rosia Montana area is that the new mine will generate numerous jobs from both the mine construction and operation and support activities. Gabriel Dumitrascu, a former Director of Rosia Montana Gold Corporation mentioned in an interview with BBC (Galor, 2002) that, including support activities, approximately 3000 new jobs will be created. This is a very important argument in a region that suffers from chronic unemployment. Young people will not be forced to leave and the local economy will be revitalized creating-Gabriel claims-long-term opportunities for families in the area.

In many of their optimistic declarations, company officials advanced different numbers for the jobs that will be created at Rosia Montana ranging from 3000 to 15,000 . Analyzing the feasibility study prepared by Gabriel, Chambers (2003) noted that only 558 jobs are scheduled to be created during operation. Even if five to seven support jobs will be created for every mining job-as the company claims-the situation will not look much better. These job opportunities would attract workforce migration in the area with negative social impacts and once the exploitation is finished, it would leave behind a great number of unemployed people, hard to reconvert (Chambers, 2003).

\section{Discourse on Resettlement}

Two ideas are highlighted in all company documents pertaining resettlement: a) that this is a voluntary process and they consulted with local population, and b) resettlement will actually improve the life of the local population.

All company documents emphasize "consultation with local population in the development of a detailed action plan and budget for resettlement."12 Several meetings with local people were organized where the necessity and advantages of resettlement were clearly explained to them and the locals showed their support to the project. According to company officials, no complaints were expressed at these meetings:

\footnotetext{
${ }^{12}$ Second Quarter Project Update- 2003, www.gabrielresources.com
}

"During the course of the approval process for the PUZ", public meetings were held with the local communities in Abrud. At these meetings, which are an integral part of the approval process for the PUZ, all parties affected by the proposed land use regulations were given the opportunity to participate in the process and ask questions. No opposition to the proposed mine development was expressed at the meetings while an overwhelming majority of persons present expressed support for the proposed development. ${ }^{, 14}$

The company negotiates individually with each landowner, very sensible to everybody's particular needs and compensations were generous. According to their website, RMGC has acquired more than 77 percent of all necessary residential properties and, although the program is now proceeding slower than expected, the company officials are optimistic that the program will be completed as scheduled. The company has invested US\$32 million to build a new village at Piatra Alba for those who want to relocate. The village has 125 houses and 24 hectares of land. Another neighborhood was built in Alba Iulia, the county capital, but most families received money which allowed them to relocate wherever they wished. Although the project summary for this project (GRD Minproc Limited, 2001) states that the resettlement shall be carried out on a voluntary basis, the following statement found in the same document invites for speculations:

"Involuntary resettlement should be minimized where feasible, exploring all viable alternative project designs ${ }^{15}$.”

The conclusion the reader gets from this statement is that an "involuntary resettlement" is not excluded only minimized. Gabriel Resources presents itself as a company that is very much concerned for the well being of the people that they try to resettle. Several documents on their websites present the company's interest to work with the World Bank Group and the IFC "to update, upgrade and improve its resettlement and relocation plan to bring it into more detailed compliance with all relevant WBC/IFC guidelines and policies. ${ }^{116}$ Experts in European laws, however, argue that the European Convention for the Protection of Human Rights and Fundamental Freedoms (ECHR), which Romania ratified, grants inalienable rights to the individuals. This makes it illegal for the company or the state to resettle by force (Fisher and Lengauer, 2002).

Articles published on industry-friendly websites claim that the fact that close to $80 \%$ of the residents

\footnotetext{
${ }^{13}$ In Romanian Plan Urbanistic Zonal or Regional Urban Plan.

${ }^{14}$ Friday October 11, 2002- Rosia Montana Project-Project Update, www.gabrielresources.com

${ }^{15}$ On page 90.

${ }^{16}$ Second Quarter Project Update-2003, www.gabrielresources.com
} 
sold their property to Gabriel Resources indicates their support for the project (Smith and Walsh, 2007). However, even if the people from Rosia Montana will agree to resettle or relocate many problems are foreseeable for the future. In an interview taken by Ion Longin Popescu $(2003)^{17}$ in Formula As, Michael Cernea, a sociologist and an expert with the World Bank revealed that, although the compensations paid are quite attractive, Cernea noted that this plan set the community against each other as some want to sell and others do not. For example older people feel more attached to their house and land while their children are more willing to accept an offer that includes a job and access to modern amenities.

Another element of the company's discourse on resettlement is the claim that the local people's life will actually improve significantly by moving into the new houses. They trade-company officials arguemostly dilapidated houses with modern ones that have all the amenities (Smith and Walsh, 2007). An anonymous writer ${ }^{18}$ to the Mineweb (2002), an online mining newspaper described the resettlement "dilemma" this way:

"The villagers of Rosia Montana, underemployed and currently living in picturesque dwellings with bronze-age plumbing (pit latrines with hole) and direct sewerage discharge into the water table drawn on by their handcranked wells (I kid you not) seemed more than happy at the prospect of being relocated to post-19 ${ }^{\text {th }}$ century housing and to have the chance of jobs that pay real wages."

The Company contended that the new site for the village, extending on 186 ha, will include all community infrastructure and public facilities such as a hospital, school, community center, library, churches and government offices as well the residential neighborhoods. ${ }^{19}$ This looks so great and apparently unchallengeable. But sociologists and other experts point to the fact that Rosians are farmers and all their life they raised cows, pigs and chicken and tended small gardens, which supplemented their income. This will not be possible anymore in the new residential neighborhoods. Moreover, people will have to pay higher prices for utilities and possibly higher taxes (Popescu, 2003).

Most of the criticism point to the fact that not only people but also churches and cemeteries will have to be moved. Also the Roman galleries and many possible archaeological pieces will be destroyed in this operation. The Company claims that they initiated and funded an archaeological research

\footnotetext{
${ }^{17}$ Translated by Crina Resteman, PATRIR, Cluj-Napoca.

${ }^{18}$ This is not an official view of the company.

${ }^{19}$ Rosia Montana Project-Positive Romanian Parliamentary

Commission Report, www.gabrielresources.com
}

program "to systematically explore all areas where mining operations and their associated plant, facilities and infrastructure will be located." This project employed up to 90 archaeological researchers and specialists, together with around 300 temporary filed workers at a total cost of $\$ 2.5$ million. For this, according to Gabriel, the company received the "Constantin Daicoviciu" award from the Romanian Minister of Culture for excellence in archaeological programs conducted during 2001. ${ }^{20}$ Moreover, in 2003 the Company received the archaeological discharge certificate that allows them to start the mining project.

There are many voices, however, accusing the company for rushing with the archaeological project and destroying valuable pieces. On April 25, 2003, Geza Alfoldi, professor at the University of Heidelberg, Germany and Ioan Piso, professor at the University of Cluj, Romania announced that 1000 scholars and scholarly institutions have signed a protest against the destruction of Rosia Montana's archaeological treasures by a commercial mining project. $^{21}$

Numerous religious leaders are opposed to the plan of moving the nine churches and eight cemeteries. Some priests refused any discussion about resettlement. For example, father Mera spoke about the planned destruction of Rosia Montana's churches and cemeteries and concluded (quoting Matthew 23:16-17): "In Christian religion the buried brothers and sisters are sleeping until Jesus Christ's second coming. If RMGC believe that they are above Jesus Christ, then there is nothing more to say."22 The Orthodox Archbishop of Alba Iulia agreed initially to negotiate with the company demanding proper compensation in exchange for resettlement. In November 2003, however, the highest authority in the Orthodox Church declared itself against the mining project hoping that the area will remain untouched in its sacredness, purity and beauty (Dobre, 2003).

\section{Discourse, Globalization and the European Union}

The mining project at Rosia Montana was initiated by Gabriel Resources in the mid 1990 and for the first several years it encountered virtually no opposition from the Romanian civil society. The project was shaped solely through discussions with the central government as the Company felt little need to enter into a dialogue with the local community. Also, by

\footnotetext{
${ }^{20}$ Gabriel Resources Ltd.- News Releases,

www.gabrielresources.com

21" How many more experts will it take", www.rosiamontana.org

22 (www.rosiamontana.org).
} 
the beginning of the 2ooos the Romanian NGOs were underfunded and too weak to vigorously oppose a project developed by a transnational corporation.

The first protest of the civil society emerged in 2000 when a group of landowners, realizing that the company started to acquire local property even before they had all the permits in place, founded a local organization to collectively oppose the company's plan. This NGO was named Alburnus Maior after the Roman name of the Rosia Montana village. However, its members, mainly farmers and mining engineers lacked experience and resources to seriously challenge the well-connected executives of the multinational mining company.

At the beginning they did little more than writing letters to Romanian authorities that were never answered (Parau, 2009). These tactics yielded no results. However, Alburnus' strategy changed in 2002. This year is associated with the globalization and internationalization of the ecological movement in Romania. This internationalization was realized in several ways:

1. Foreign activists started to join the Romanian NGOs. For example, in mid 2002, a former journalist from The Ecologist, Stephanie Roth, joined Alburnus Maior. In motivation of her decision, she later mentioned in an interview that she was impressed by the weakness of the organization in dealing with a government which abusively allowed a transnational corporation to begin mining in a protected area and in so doing it has denied the right of the local people to decide for their future (Parau, 2009; Roth, 2002). Roth moved immediately to professionalize the Alburnus' campaign by introducing the ideology and methods used by environmental organizations in the developed world. Some of these methods, widely used in the West, but novel in Romania, like lobbying and lawsuits proved to be very successful.

2. The new international experts at Rosia Montana acted very quickly to forge alliances with wellestablished transnational environmental organizations such as Greenpeace, CEE BankWatch and Mining Watch Canada. This has brought increased international exposure and unprecedented press coverage (Parau, 2009).

3. The international activists not only brought their own expertise to work for the Rosia Montana cause but also mobilized to raise transnational funds (Parau, 2009). This allowed Alburnus to hire legal and technical experts to challenge the company's claims in terms of the legality and feasibility of the project. They also managed to coalesce against the mining project many different organizations and institutions from Romania such as the Romanian Academy.

4. Following all these, Alburnus started lobbying not only the Romanian government in Bucharest but also (and especially) political factors in Brussels and elsewhere.

5. After the ecological disaster in Baia Mare in 2000 it became clear that environmental management in case of such large mining projects is not solely a problem of Romania but should also involve neighboring countries. Indeed, following the Baia Mare ecological accident, Hungary has become one of the most active against the projects (Alburnus Maior, 2007). Hungary's actions were justified by the Espoo Convention on Environmental Impact Assessment in cases of trans-boundary ecological situations but Parau (2009) argues that Alburnus Maior and the transnational alliance of environmental organizations may also had a role in lobbying the Hungarian government to get involved.

Due to this offensive by the environmentalist groups, the company also had to reconsider its discourse. Whereas previously it considered that having a good relationship with the Romanian government and bringing jobs to a very poor region of the country was enough to advance with the project, now it found that it was necessary to adopt the sustainable community development strategy and rhetoric already employed by the mining industry elsewhere if it wanted to continue with the project. By so doing both discourses were internationalized and were stressing sustainable development by 2003 .

Romania's prospect for joining the European Union has offered another "battlefield" for the two discursive movements which then intensified after accession in 2007. The environmentalist movement used this opportunity in two ways:

1. It started lobbying in Brussels against the project. While, in general, no European official took a stand against the opening of the mine at Rosia Montana, the Europeans started paying more attention to what was happening there which signaled the Romanian authorities that, by authorizing the project, they would load themselves with huge political responsibilities.

2. By emphasizing the need for Romania to harmonize its legislation with the European acquis. It also induced the idea that the European legislation may be much stricter. For example, Alburnus Maior claims that experts from the European Union Law Institute testified that the project is not in accordance with the European Legislation and that many countries in Europe 
have already banned or are thinking of banning the use of cyanide (Roth, 2002)

This new tactic put the company on defensive as it was forced to play by the environmentalists' rules. Its experts have immediately pointed out that only Czech Republic of all the EU countries has banned the use of cyanide in gold mining and that 12 of the 15 currently operating gold mines in Europe use cyanide, including gold mines in Sweden, Finland and Spain. The company also argues that it has designed the project to be compliant with all EU directives from day one.

There are several studies on the legislative response of the European Union to the catastrophic mining related events in 1998 at Aznacollar, Spain and 2000, at Baia Mare, Romania (Hamor, 2004). These show that the legislative framework has indeed become stricter since these accidents but nothing point to the illegality of the Rosia Montana Project.

\section{Conclusions}

Discourses are socially constructed ideas representing the particular standpoint of certain institutions. The discursive movement tends to either reinforce or challenge existing social and economic arrangements. Any statement should be viewed through the lenses of the institutional group making the statement rather than accepted as an absolute truth. Also, as this and previous studies have demonstrated, discourses are not static or ahistorical; they change in time as they compete with each other to win more support.

One area where this discursive antagonism is very evident is around major mining projects where the large-scale, open-pit operations have a significant environmental, economic and social impact on a regional level. While the new technologies used have increased the profitability of the industry, they have also limited the number of people directly or indirectly benefiting from a new mining project. On the other hand, the large-scale operations have increased the environmental destruction affecting the livelihood of people on a much larger area. This has contributed to the rise of the environmentalist movement.

In the past, the dominant discourse surrounding the mining operations was built around the idea of development and modernity and emphasized the productive power of technology over nature. Today, with the rise of the environmentalist groups, two discourses are competing for the dominant position. Both groups have appropriated the idea of sustainable development; however, they approach it from different perspectives.
The mining industry argues that large-scale mining development, with all the benefits that it brings to the local communities is possible without destroying the environment. On the other hand, the environmentalists claim that they are not against local or regional development per se, only against large mining projects which they do not consider to be compatible with environmental protection. Instead they are in favor of developing more sustainable economic activities.

The discourse associated with the mining company at Rosia Montana follows in general the same model discussed by Bridge (1998, 2000, 2003) and Bridge and McManus (200o). While during the 1990s, Gabriel Resources emphasized in its discourse the new mining project's ability to provide jobs and revitalize the mining industry in the region, after 2000, in response to the offensive of a transnational environmentalist movement, it embraced the rhetoric of sustainable development. The company claimed that the latest technologies employed by the company will ensure that the great economic and social benefits for Romania and for the local community will not come at the expense of the environment. Moreover, not only the project will not generate pollution, but also will clean the historical pollution in the region.

As expected, the numerous NGOs implicated as well as foreign organizations like Greenpeace harshly criticized the project showing its immense and irreversible environmental, economic and social implications. Both sides use science to demonstrate the validity of their theory although giving a different interpretation to the results. This shows, perhaps that they are addressing a more educated public than in the past.

The evolution of the two competing discourses around the Rosia Montana mining project was also influenced by the globalization and internationalization of the ecological movement in Romania. This has been realized with the help of foreign activists joining Romanian NGOs, through the adoption by the Romanian NGOs of the ideology and methods used by environmental organizations in other parts of the world, through establishing transnational alliances with global and international organizations and through the ability of the new international activists to raise transnational funds and to hire international experts.

Confronted with this metamorphosis of the environmental opposition group, Gabriel Resources, the transnational corporation developing the largest European mining project in Romania was forced to change its rhetoric. Its refurbished discourse, centered on the ideas of sustainable development and corporate social responsibility, resembles more and 
more with the discursive practice of the industry in the Western world.

This study has also showed that, local factors like Romania joining the European Union, previous experiences with ecological disasters caused by mining companies and the existence of archaeological vestiges in the area have also greatly influenced the rhetoric of the stakeholders. Among these factors, the most important is Romania's recent accession (2007) to the European Union. This has influenced the discursive practices in two major ways. Firstly, other EU members (such as Hungary), most likely to be affected in case of an ecological disaster have also become involved in the controversy. Secondly, both sides use European mining practices and legislation in order to support their argument on the legality and feasibility of the proposed mining project.

\section{Bibliography}

Alburnus Maior 2007, Rosia Montana: Gold Mine Proposal Provokes International Opposition, www.ngo.ro.

Abrudan, I \& Turnock, D 1999, 'A Rural Development Strategy for the Apuseni Mountains, Romania', GeoJournal, vol. 46, nr. 3, p. 319-336.

Bechir, M 2003, 'Proiectul Rosia Montana, Obstacol spre Europa', Evenimentul Zilei, viewed on 11 December 2003, www.evz.ro.

Beck, U 1992, Risk Society: Towards a New Modernity, Sage Publications, London.

Bridge, G 2003, 'Local Dirt, Global Dreams: Mining Investment and Land Use Change in Arizona', Local Environment, vol. 8, nr. 1, p. 61-83.

Bridge, G 2000, 'The Social Regulation of Resource Access and Environmental Impact: Production, Nature and Contradiction in the US Copper Industry', Geoforum, vol. 31, nr. 2, p. 237-256.

Bridge, G 1998, 'Excavating Nature. Environmental Narratives and Discursive Regulations in the Mining Industry', in A Herod, GO Tuathail \& SM Roberts (eds.), An Unruly Word? Globalization, Governance and Geography, Routledge, London and New York.

Bridge, G \& McManus, P 2000, 'Sticks and Stones: Environmental Narratives and Discursive Regulation in the Forestry and Mining Sectors', Antipode, vol.32, nr.1, p. $10-47$.

Buza, M, Dimen, L, Pop, G \& Turnock, D 2001, 'Environmental Protection in the Apuseni Mountains: The Role of Environmental Non-Governmental Organizations (ENGO's)', GeoJournal, vol. 54, nr. 2-4, p. 631-653.

Chambers, DM 2003, Technical Comments on the Rosia Montana Feasibility Study and the Rosia Montana Project Description, Bozeman, MT, Center for Science and Public Participation,

http://www.csp2.org/reports/Rosia\%2oMontana\%2oProje ct\%2oDescription\%2oComments\%201.13.03.pdf.

Clover, C 200o, 'Romanians Blamed for Cyanide Pollution of Rivers', Telegraph, Issue 2033, viewed on 18 December 200o, http://www.telegraph.co.uk.
Dobre, L 2003, 'Sfantul Sinod E Impotriva Proiectului Rosia Montana', Ziua, viewed on 13 November 2003, www.ziua.ro.

Fisher, P \& Lengauer, A 2002, The Compatibility of the Rosia Montana Mining Project in Romania with the Principles and Norms of EU and EC Legislation- An Expert Opinion, Institute of Law, University of Vienna.

Frynas, JG 2005, 'The False Developmental Promise of Corporate Social Responsibility: Evidence from Multinational Oil Companie', International Affairs, vol. 81, nr. 3, p. 581-598.

Gergely, K 2000, 'The Tisza River: To Be or Not To Be?', Chemical Awareness, Issue 11, viewed on 23 October 2000, http://zpok.hu/cyanide/baiamare/News/chemaaware.ht m.

Gabriel Resources Ltd. 2003, 'News Releases', http://www.gabrielresources.com.

Galor, D 2002, 'Proiectul Rosia Montana', BBC-Romania, 30 November 2002. Found in a brochure edited by Departamentul pentru Analiza Institutionala si Sociala (Department for Institutional and Social Analysis), www.bbc.co.uk/Romanian/.

GRD Minproc Limited 2001, 'Rosia Montana ProjectProject Summary', Company Document, www.gabrielresources.com.

Hamann, R \& Kapelus, P 2004, 'Corporate Social Responsibility in Mining in Southern Africa: Fair Accountability or Just Greenwash?', Development, vol. 47, p. $85-92$.

Hamor, $\mathrm{T}$ 2004, 'Sustainable Mining in the European Union: The Legislative Aspect', Environmental Management, vol. 33, nr. 2, p. 252-261.

Hoenneland, G 2003, 'Industrial Pollution Discourse in the European Arctic', Acta Borealia, vol. 2o, nr. 1, p. 49-73.

Hutchins, MJ, Walck, CL, Sterk, DP \& Campbell, GA 2005, 'Corporate Social Responsibility: A Unifying Discourse for the Mining Industry?', Greener Management International, vol. 52, p 17-30.

Jenkins, H \& Obara, L 2008, 'Corporate Social Responsibility (CSR) in the Mining Industry - The Risk of Community Dependency', CRR Conference, 7-9 September 2008, Queens University, Belfast, http://www.crrconference.org/downloads/2006jenkinsob ara.pdf.

Kemp, D 2010, 'Mining and Community Development: Problems and Possibilities of Local Level Practice', Community Development Journal, vol. 45, nr. 2, p. 198-218.

Kepore, KP \& Imbun, BY 2010, 'Mining and Stakeholder Engagement Discourse in a Papua New Guinea Mine. Corporate Social Responsibility and Environmental Management', published online 20 July 2010 http://onlinelibrary.wiley.com/doi/10.1002/csr.243/pdf.

Krueger, R 2002, 'Relocating Regulation in Montana's Gold Mining Industry', Environment and Planning A, vol. 34, nr. 5, p. $867-881$.

Manteaw, B 2007, 'From Tokenism to Social Justice: Rethinking the Bottom Line for Sustainable Community Development', Community Development Journal, vol. 43, p. 428-443

ML 2003, 'Academia Contra Roşia Montana', Ziua, viewed on 30 May 2003, www.ziua.ro.

Mihaescu, R \& Floca, L 1999, 'Shifting in Environmental Problems in Transition Period: Mountain Area (Apuseni)', 
in V Surd (ed.), Rural Space and Regional Development, Editura Studia, p. 246-251, Cluj-Napoca.

Mineral Policy Center, Alburnus Maior and CEE Bankwatch Network 2002, 'Evaluating Risk. Investors' Guide to Gabriel Resources Limited's Rosia Montana Mine Proposal', Corporate Research Bulletin, viewed on November 2002, www.earthworksaction.org/pubs/EvaluatingRisk.PDF.

Mineweb 2002, Rosia Montana-Greenies Prefer Degradation to Cleaner Alternative, http://www.mipsi.net.

MiningWatch Canada 2002, Romanian Villagers Oppose Canadian Gold Mine at Rosia Montana, http://www.miningwatch.ca.

Northover, R 200o, 'Eastern Europe Gets Toxic Shock', BBC, viewed on 14 February 2000, www.bbc.co.uk/nature/animals/news/122news5.shtml.

Parau, CE 2009, 'Impaling Dracula: How EU Accession Empowered Civil Society in Romania', West European Politics, vol. 32, nr. 1, p. 119-141.

Peet, R \& Watts, M 1996, 'Liberation EcologyDevelopment, Sustainability, and Environment in An Age of Market Triumphalism', in R Peet \& M Watts (eds.), Liberation Ecologies- Environment, Development and Social Movements, Routledge, 1-45, London and New York.

Popescu, IL 2003, 'The Truth about the Resettlement of the Apuseni Mountains. Interview with Michael M. CerneaSociologist and World Bank Expert, Washington D.C', Formula As, nr. 582, viewed on September 2003, www.formula-as.ro.

RMGC (Rosia Montana Gold Corporation) 2003, Rosia Montana Mine Project Overview, www.rosiamontanagoldcorp.com/eng/projectdesc.htm.

Roth, S 2002, 'New Mine Scheme Threatens Romania', The Ecologist, viewed on July - August 2002, http://www.theecologist.co.uk/archive.

Rusu, M, Marghitas, M, Munteanu, V, Balutiu, C, Paulette, L, Popa, M \& Tudoran, A 2001, 'Contributii la Cunoasterea
Acumularii Metalelor Grele ( $\mathrm{Pb}, \mathrm{Cd}, \mathrm{Cu}, \mathrm{Zn})$ în Solurile şi Vegetatia Zonei Zlatna', Annales Universitatis Apulensis: Topografie- Cadastru, vol. 1, p. 101-107.

Schmink, M \& Wood, CH 1987, 'The 'Political Ecology' of Amazonia', in PD Little, MH Horowitz \& AE Nyerges (eds.), Lands at Risk in the Third World, Boulder, Westview Press, pp. 38- 57.

Simion, S \&. Brand-Jacobsen, KF 2002, 'Rosia Montana: Cyanide in a Community - Ecology, Corporate Profit, and the Struggle for People's Rights', Cluj, PATRIR, http://www.hartford-hwp.com/archives/62/46o.html.

Smith, F Jr. \&. Walsh, J 2007, 'A Village's Travail: A Snapshot of Environmental NGO's Real Work', Competitive Enterprise Institute, nr. 120, viewed on 12 September 2007, http://cei.org/pdf/6132.pdf.

Stirban, M, Osvath, T \& Deliu, C 1980, 'Estimari Comparative ale Influentei Poluarii Asupra Potentialului Reproductiv al Fagetelor din Valea Ampoiului', Buletinul Centrului de Cercetari Biologice, 20: 376-386, Cluj Napoca.

Surd, V \& Turnock D 200o, 'Romania's Apuseni Mountains: Safeguarding A Cultural Heritage', GeoJournal, vol. 50, nr. 2-3, p. 285-304.

The Sydney Morning Herald 20oo, 'Hungary to Sue for $\$ 181$ Million', viewed on 11 July 2000, http://www.smh.com.au/news/specials/intl/cyanide/inde x.html.

Toader, M 2003, 'Nastase in Recital', Ziua, viewed on 6 June 2003, www.ziua.ro.

Ungureanu, C \& Ragalie, S 2009, 'Promoting Rural Tourism: Viable Option for Rosia Montana Economic Area Development', Oesterreichisch-Rumaenische Akademische Verein, paper 2009/7

Vidal, J 2002, 'Bank Pulls Plug on Open-Cast Gold Mine', The Guardian, viewed on 12 October 2002, www.guardian.co.uk.

Willems-Braun, B 1997, 'Buried Epistemologies: The Politics of Place in (Post)colonial British Columbia', Annals of the Association of American Geographers, vol. 87, nr. 1, p. 3-31. 